\title{
Alterations in Retinoic Acid Receptors in Non-Small Cell Lung Cancer and Their Clinical Implications
}

\author{
Saé Muñiz-Hernández¹, Norma Hernández-Pedro', Omar E. Macedo-Pérez², \\ Oscar Arrieta ${ }^{1,2 *}$ \\ ${ }^{1}$ Experimental Oncology Laboratory, Subdirección de Investigación Básica, Instituto Nacional de Cancerología, \\ Secretaría de Salud, Mexico City, Mexico \\ ${ }^{2}$ Department of Medical Oncology, Instituto Nacional de Cancerología, Mexico City, Mexico \\ Email: ogar@unam.mx
}

Received 12 May 2015; accepted 25 July 2015; published 28 July 2015

Copyright (C) 2015 by authors and Scientific Research Publishing Inc.

This work is licensed under the Creative Commons Attribution International License (CC BY). http://creativecommons.org/licenses/by/4.0/

(c) (i) Open Access

\section{Abstract}

The nuclear retinoic acid receptor may play a critical role in the process of lung carcinogenesis. Alteration or loss of nuclear retinoic acid receptors (RARs) has been associated with progression in premalignant and malignant tissues and it is associated with malignant transformation in human cells. Vitamin A derivates, such as retinoic acid, have emerged as adjuvant to therapy in several types of cancer with favorable effects. Retinoic acid regulates the expression of target genes through the binding and activation of RARs, inhibiting growth proliferation. Diverse studies have evaluated different retinoids alone or in combination with chemotherapy in lung cancer, from which results have been controversial with benefits observed only in the subpopulation with high levels of triglycerides. Additionally, several large randomized trials using retinoids to prevent tobacco-related cancer have failed; due to the latter the use of retinoids in clinical trials remains controversial. However they could reduce the risk of cancer development in non-smokers. There is evidence that retinoids have different effects on lung cancer; still the identification of biomarkers could determinate their benefits as preventive or therapy agents. This review describes the RAR alterations during the development of Non-Small Cell Lung Cancer and sets out the importance of several cancer treatments with retinoid compounds.

\section{Keywords}

Cell Transformation, Neoplastic, Neoplasms, Receptors, Retinoic Acid, Biological Markers, Retinoids

\footnotetext{
"Corresponding author.
}

How to cite this paper: Muñiz-Hernández, S., Hernández-Pedro, N., Macedo-Pérez, O.E. and Arrieta, O. (2015) Alterations in Retinoic Acid Receptors in Non-Small Cell Lung Cancer and Their Clinical Implications. Journal of Cancer Therapy, 6, 648664. http://dx.doi.org/10.4236/jct.2015.68072 


\section{Retinoids}

The retinoids are a wide group of compounds, derived from Vitamin A, which are required for maintaining many essential physiological processes, such as: embryonic development, cell growth, differentiation and apoptosis [1] [2]. The metabolism of retinoids is complex and involves several natural derivatives and metabolized products of retinoids, such as: $\beta$-carotene, retinol, retinal, isotetrinoin, all-trans retinoic acid (ATRA), 9-cis retinoic acid (9-cis-RA), and 13-cis retinoic acid (13-cis-RA), which act as ligands for multiple nuclear hormone receptors [2] [3]. Retinoic acid (RA) is the most biologically active isoform; it activates several members of the nuclear receptor family, including the classic retinoic acid receptors (RARs) [4] as well as the peroxisome proliferator-activated receptor $\beta / \delta(\operatorname{PPAR} \beta / \delta)$ [5] [6]. Upon activation, these receptors modulate the transcription of numerous target genes, either by inducing or repressing them [7] [8]. In addition RA treatment is able to induce RAR $\beta$ expression in the peripheral nervous system [9] [10].

\section{Nuclear Retinoic Acid Receptors: Retinoic Acid Receptors (RARs) and Retinoid X Receptors (RXRs)}

The functions of RA signaling are mediated by two different classes of receptors, the Retinoic Acid Receptors RARs) and the Retinoid X Receptors (RXRs), each class with three different subtypes ( $\alpha, \beta$ and $\gamma$ ). The RARs and RXRs exhibit differential trans-activation activity when evaluated in several, synthetic or natural, retinoic acid-responsive genes; the latter depending on the nature of the retinoic acid response elements (RARE) and the promoter context [11]. While RARs can be activated by ATRA and 9-cis-RA, RXRs are exclusively activated by 13-cis-RA and bexarotene; however, ATRA can presumably activate RXRs through its isomerization to 9-cis-RA, which is known to occur in living cells [12] [13]. Under physiological conditions, the function of both RARs and RXRs in the regulation of endogenous gene expression is through heterodimer binding. The heterodimers bind to specific response elements (e.g. RAREs and RXREs) in genes promoter regions via their specific DNA-binding domains [12]. Moreover, RXRs can formhomo-and heterodimers with other receptors, i.e., peroxisome proliferator-activated receptor gamma (PPAR- $\gamma$ ), fatty acids receptors, bile acids, oxysterols, xenobiotics, vitamin D and retinoic acid; the latter plays an important role in antiproliferative, antiangiogenic, and pro-differentiation pathways in several types of tissues, making it a highly useful target for carcinogenesis down-regulation [14].

The RARs and RXRs are comprised of three different types of receptors $(\alpha, \beta, \gamma)$, and for each there are several isoforms. The RAR- $\alpha$ and RAR- $\gamma$ have two major isoforms ( $\alpha 1, \alpha 2$ and $\gamma 1, \gamma 2$, respectively), while RAR- $\beta$ has five isoforms ( $\beta 1-4$ and $\beta 1$ '). Every isoform is transcribed from either the P1 promoter (class I: RAR $\alpha 1, \beta 1$, $\beta 3$ and $\gamma 1$ ) or the P2 promoter (class II: RAR $\alpha 2, \beta 2, \beta 4$ and $\gamma 2$ ); the latter composed of a retinoic acid response element and inducible by RA [2] [15]. Meanwhile the RXR shave three isoforms $(\alpha, \beta$ and $\gamma)$, with each subtyoe separated in two isoforms $(\alpha 1, \alpha 2, \beta 1, \beta 2, \gamma 1$ and $\gamma 2)$ with different amino-terminal regions. The RXRs work as a transcription factor, binding to specific six-base-pair sequences of DNA in the promoter regions of genes.

The human RARs are encoded by separate genes with well-characterized chromosomal location, as follows: 17q21.1 (RAR $\alpha$ ), 3p24 (RAR $\beta$ ) and 12q13 (RAR $\gamma$ ) [16]. Figure 1 shows a representative scheme of the amino acid sequences dividing the RARs into six regions (A-F) based on homology among themselves and other nuclear receptor super family members (reviewed in [16]). The C region has a highly conserved sequence of 66 amino acids that contains two zinc fingers which correspond to a DNA binding domain (Figure 1, DNA-BD) responsible for specific response element recognition. The E region (Figure 1, ligand BD) is highly conserved too, and it functions as a ligand-binding domain; this function is complex, including a ligand-dependent transactivation function as well as a dimerization interface. The amino-terminal region of these molecules (Figure 1, A) is type- and isoform-specific, the B region is moderately conserved in the three types of the RARs. Both the A and B regions contain ligand-independent trans-activation functions. Currently the specific functions of regions $\mathrm{D}$ and $\mathrm{F}$ are unknown, although they are well conserved through several species. The central part of the RAR D region and its amino-terminal could work as nuclear localization signals due to their high number of basic amino acids [16] [17].

Regarding the RXRs, their sequence is divided into several regions, which possess the same inter-type domain conservation as RARs [16] [17]. The RXRs are encoded by three distinct genes located on the human chromosomes 9 (RXRA, also known as NR2B1), 6 (RXRB, NR2B2), 1 (RXRG, NR2B3), and the mouse chromosomes 2, 17 and 1 [18] [19]. The human RXR $\alpha$ gene has 10 conserved exons but not a typical TATA transcription 


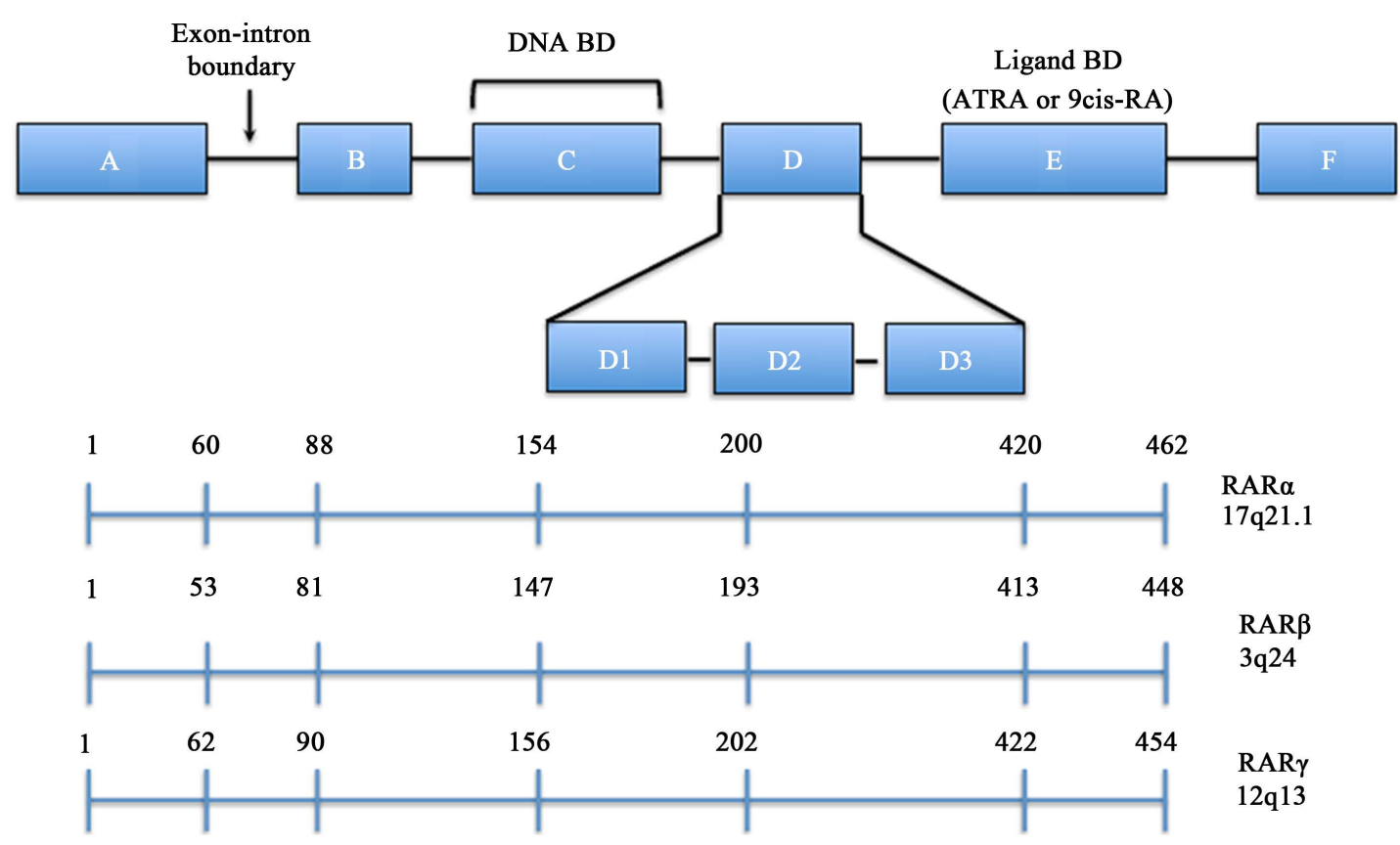

Figure 1. Representative scheme of conformation of acids of human RAR.

initiation site [20]. Its promoter sequence is considered a housekeeping gene because it is particularly rich in G + C content in its 5'-flanking region and in the 5' portion of the intron 2, containing CpG islands [19] [20]. The human $\operatorname{RXR} \beta$ gene has as well the same exons and promoting regions as $\operatorname{RXR} \alpha$ [21].

The differences between the response profiles for each of the RARs have been used to evaluate their participation in multiple cellular processes, with an attempt to correlate with new the rapeutic applications.

\section{Expression of the RARs and RXRs in Lung Development}

Mammalian lung differentiation is regulated by the expression of RARs and RXRs during progressive stages throughout the embryonic and postnatal life. These receptors are expressed in spatially-and temporally restricted patterns and have different ways of regulation during the development of the lung.

In early stages of lung development, RAR- $\alpha$ is associated with instructing epithelial cell differentiation and drives the structural changes during the transition from the glandular to the canalicular stage in the lung. As regards of murine alveologenesis, a morphometric study of the formation of the RAR $\alpha-1-$ in mice found no difference between control and knockout animals at the end of the alveolar septation, suggesting that RAR- $\alpha$ has no effect on septation but a role on non-septation alveologenesis [22]. The RAR- $\alpha$ was expressed in all cells for fetal and adult lungs, with a different pattern of expression. Whereas in the fetal lung the RAR- $\alpha$ is low, in the adult lung both, RAR $\alpha$ and $\operatorname{RXR} \alpha$, show a high immunoreactivity [23]. Correspondingly, when there is a disruption between the RAR- $\alpha$ with the RXR- $\alpha$, there is an associated fetal lung hypoplasia [24]. In the same way, during murine alveogenesis, the use of a specific RAR- $\beta$ agonist, causes the RAR- $\beta$ to act as a negative regulator of septation. The analysis of a different RAR- $\beta$ mutation showed different results with a reduction in the gas exchanging surface area per lung volume [25] [26]. The RAR- $\beta$ expression is significantly increased in the terminals accular stage, with induction of epithelial cell types I and II [27]-[29].

Analyses of the RAR double mutants, such as $\operatorname{RAR} \alpha$ and $\beta$, show them as critical receptors for the development of lung abnormalities. Alteration of RAR $\alpha$ and $\beta$ double null mice includes manifestations such as: unilateral lung agenesis and unilateral or bilateral lung hypoplasia [25]. Intriguingly, single knockout RAR mice show no abnormal lung phenotype [26]. Genetic analysis of the functions of the various RARs and RXRs in the fetal lung of the mouse have been reported for singles and mutants. RXR- $\alpha /$ RAR- $\alpha$ and RAR- $\alpha /-\beta$ double knockout mice have been shown to have hypoplasia of the lung and to lack the esophagotracheal septum [24] [25]. Mice with a single RAR- $\beta$ knockout were found to have normal lungs [27] [28], but the inhibitory effects of RA on distal bud formation in the lungs were markedly diminished in these RAR- $\beta$ null mouse during the 
pseudo glandular phase of development [29]. Therefore, retinoid receptors are believed to be one of the pivotal factors determining the process of branching morphogenesis in the mouselung. Additionally the distributions of RAR $-\alpha,-\beta$ and $-\gamma$ and RXR- $\alpha$ and $-\beta$ have been demonstrated during the pseudo glandular phase in the fetal lung of the mouse by mRNA in situ hybridization [30] [31].

The RAR- $\gamma$ is expressed in the murine lung during embryogenesis, primarily in late gestation and appears in the distal lung mesenchymal cells [32]. The RAR- $\gamma$ null mutant mouse fails to correctly form alveoli, while the RAR- $\gamma$ gene deletion also results in a decrease in whole lung elastic tissue and alveolar number, with an increase in mean alveoli cord length [33]. The RAR- $\gamma$ knockout mice had malformed cartilages in the trachea and bronchi [32] [33]. The additional deletion of the RXR- $\alpha$ allele results in a decrease in alveolar surface area and alveolar number, and an increase in alveoli length. These data indicate that the RAR- $\gamma$ is required for the formation of normal alveoli and alveolar elastic fibers in the mouse, and that RAR/RXR heterodimers are involved in alveolar morphogenesis. In early onset stage of alveolar air-space enlargement, mice with RAR- $\gamma-/-$ develop defects in alveolar formation, rather than excessive elastic fiber destruction [33]. Analysis of the RAR- $\gamma-/-/ \mathrm{RXR}-\alpha+/-$ compound null mutants has revealed defects in alveologenesis, suggesting that either RAR- $\gamma 2$ may function as a positive regulator of alveologenesis or RAR- $\beta 2 / \mathrm{RAR}-\beta 4$ may function as negative regulators of alveologenesis [32].

The expression of RAR $-\gamma, \mathrm{RXR}-\alpha$, and RXR $-\gamma$ in morphologically restored epithelium of subjects with severe asthmas was observed throughout the epithelial layer, suggesting widespread functional changes in relation to the repair process. A univariate correlation analysis demonstrated that RXR- $\alpha$ and RXR- $\gamma$ imunostaining is positively related to the proportion of morphologically intact epithelium, suggesting that the expression of these receptors may represent an ongoing repair process. Interestingly, changes in the numbers of RAR- $\gamma$, RXR- $\alpha$, and $\mathrm{RXR}-\gamma$ positive cells paralleled those of the mucosal fibroblasts/myofibroblasts, suggesting that retinoidmediated epithelial repair may be associated with functional abnormalities that directly contribute to subepithelial fibrosis [34].

Although the previously mentioned studies implicate these receptors in lung morphogenesis, they do not define a specific role for individual RARs in this process. However, the deregulation in expression of the RARs and RXRs is a risk factor for the induction of cancer development, moreover the mechanisms that are linked to the expression or repression of this receptors remains under investigation.

\section{Genetic Alterations of RAR and RXR Expression in Lung Cancer}

Multiple impaired expression of the RARs and RXRs can occur through genetic events such as epigeneticchanges, homozygous deletion, intragenic mutation, rearrangement of chromosomal material and loss of heterozygosity (LOH) followed by a second hit, which plays a major role in cancer initiation and progression [35].

Epigenetic inactivation by aberrant methylation of $\mathrm{CpG}$ islands is a mechanism for transcriptional silencing. Multiple studies have demonstrated that this phenomenon contributes to the loss of the RARs and RXRs expression leading to the development of non-small cell lung cancer (NSCLC) [36]. A study results showed that methylation of the RXR- $\gamma$ gene was detected in $23.7 \%$ of the tumors, whereas methylation of the RXR- $\alpha$ and RXR$\beta$ genes was rarely detected (5.7\% and 4.3\%, respectively). RXR- $\gamma$ methylation was significantly more frequent in stage I tumors than in stage II-IV tumors, and it was associated with worse survival ratesin never-smokers [37].

The RAR- $\beta 2$ promoter contains a CpG island in the 5 '-untranslated region that is frequently methylated in cancer cells. Hypermethylation of RAR- $\beta 2$ can occur in tumor-adjacent or precancerous tissues provide strong evidence that RAR- $\beta 2$ silencing is an early event [38]. Observations have shown that the decrease of RAR- $\beta 2$ is more often due to the methylation affecting the RAR- $\beta$ P2 promoter of one or more RAR- $\beta$ alleles [39] [40]. Methylation of RAR- $\beta$ gene rate of NSCLC is slightly higher in stages III + IV (80.0\%) than in I + II (70.8\%) [41]. Moreover, RAR- $\beta 2$ CpG island has been found in approximately $40 \%$ of NSCLC, and similar results were obtained for the methylation RAR- $\beta$ gene between squamous cell carcinoma and other cell type lung cancer [42]. Also Kim et al. reported a protective effect of RAR- $\beta 2$ hypermethylation on the development of second primary lung cancers in smokers with NSCLC [43]. The frequency of the RAR- $\beta$ gene methylation was gradually increased with the clinical stage development in smoking lung cancer patients. The RAR- $\beta$ gene hypermethylation is associated as well with poor recurrence-free survival in never-smokers with adenocarcinoma [44]-[46].

The LOH has been identified as the initial event in lung carcinogenesis, and it is recognized in multiple 
chromosomal regions [35] [47] [48]. Frequently the 3p21 region contains a distinct locus that is sensitive to loss from the action of tobacco smoke carcinogens and has been reported as a biomarker in the genetic classification of pathological stages of NSCLC [48]-[50]. The RAR- $\beta$ is localized in the 3p21 region and the frequency of LOH reaches nearly 42\% [35] [36]. A study from Picard et al. found that $41 \%$ of the patients with NSCLC show a $\mathrm{LOH}$; interestingly differences were not found between adenocarcinomaand squamous cellcarcinoma (SCC); in which about $80 \%$ of both, adenocarcinoma and SCC with LOH, showed a weak expression or absence of the RAR- $\beta$ protein and mRNA [23].

\section{Expression of the RARs and RXRs in Lung Cancer}

Every retinoid receptors are regulated in different tissues. However, in several types of human cancers both RARs and RXRs are down-regulated. Some in vivo studies in NSCLC have demonstrated that sustained expression of RARs and RXRs are related to the formation of preneoplastic bronchial lesions; associated with a loss in RAR- $\beta$ expression, and to a lesser extent by RAR- $\gamma$ and RXR- $\beta$ in tumors [23].

Tissue of patients with stage I-IIA NSCLC showed a lack of the RARs and RXRs expression, which appeared associated with a worse prognosis, especially when two or more isotypes were altered or lost [51]. In contrast, other studies showed that a high expression of the RARs in tissues of patients with early stage of NSCLC led to poor prognosis due to decreased survival [52]. In other study, the RARs and RXRs expression were analyzed in tumor specimens from NSCLC patients, the results indicated that RAR- $\beta$ expression was absent in $58 \%$ of the samples, while RAR- $\alpha$, RXR- $\alpha$ and RXR- $\gamma$ expression were very similar between tumor specimens and normal tissue [53].

The RAR- $\beta$ has been one of the most studied RA receptor in multiple lung cancer cell lines; this receptor is suppressed or down-regulated and suggesting that the lack of expression of the RAR- $\beta$ is associated with lung cancer development. The lack of expression of the RAR- $\beta$ is initially observed during the development of premalignant lesions and suggests that this decrease is a major defect present during lung carcinogenesis [53]. The latter hypotheses is supported by a prior study where the RAR- $\beta$ expression vector was transfected in vitro into a cell line derived from an epidermoid lung tumor; post-transfection of these cells demonstrated a decreased tumorogenicity in nude mice [54]. In 39 patients with stage I NSCLC who underwent a curative lung resection, the cancer cells and adjacent normal-appearing bronchial epithelium showed no prognostic implication when the expression of the RAR- $\beta$ was studied. However, of expression of the RAR- $\beta$ appeared to be more common in adenocarcinoma samples rather than in SCC [55].

In a retrospective study, 185 NSCLC tissue specimens were analyzed and it was possible to associate the RAR- $\beta$ expression in cancer cells with a poor overall survival rate and a trend towards a worse disease-free survival rate. On this study, patients with strongly positive receptor expression had the worst overall survival while patients with negative RAR- $\beta$ expression demonstrated the best overall survival. Notwithstanding, independently of the RAR- $\beta$ expression, second primary tumor development differences in the percentage were not found [52]. This study appears to contradict prior findings that indicated that the RAR- $\beta$ was a potential carcinogenesis indicator. It is possible; that the different isoforms of the RARs could act in opposite ways to either promote or hinder cancer development.

\section{Retinoids as Therapeutic Agents in Cancer (Except NSCLC)}

Historically, natural retinoids have been used aspotential treatments; either as chemotherapeutic or chemopreventive agents, due to their role in differentiation, proliferation and/or apoptosis of cancer cells. Nowadays, in an attempt to retain antiproliferative effects of vitamin $\mathrm{A}$, there is a frequent development of synthetic retinoidsspecific to epithelial tissue and limiting retinoid-treatment side effects, such as skin and liver toxicity [56].

Retinoids, natural and synthetic, have been used in chemoprevention and differentiation therapy. For lung cancer cell lines 9-cisRA was found to up-regulate bronchial squamous metaplasia RAR expression and was able to inhibit lung cancer cell growth; suggesting that 9-cisRA could be a potential chemopreventive agent in NSCLC [57]. In human breast cancer cell lines 9-cis-RA induces cell cycle arrest and growth inhibition. In animal models, 9-cis-RA is able to enhance the chemopreventive activity of tamoxifen and inhibit carcinogenesis [58]. Additionally, the treatment with 9-cis-RA is effective for inhibiting prostate intraepithelial neoplasia for both in vitro and in vivo models by modulating nuclear and mitochondrial genes [59] [60]. In order to increase the effect of retinoids, 9-cis-RA was used in combination with different agents; for example, the combination 
with ciglitazone, a thiazolidinedione class drug, caused a synergistic inhibition in the growth of human colon cancer $\mathrm{CaCO}_{2}$ cells, this was associated with the induction of apoptosis and inhibition of the expression of both COX-2 and c-Jun proteins [61].

On the other hand, 13-cis-RA exhibits an immunomodulatory and an anti-inflammatory activity in B16F-10 melanoma cells. Treatment with 13-cis-RA showed an inhibitory effect on bcl-2 expression and up-regulated p53 and caspase-3 gene expression. It also alters the production and expression of proinflammatory cytokines [62]. In a similar manner, the combination of 13-cis-RA with cytotoxic chemotherapy significantly reduced the cytotoxicity for in vitro neuroblastoma, mediating at least partly via the anti-apoptotic Bcl-2 family of proteins [63]. Besides 13-cis-RA is given at completion of cytotoxic therapy to control minimal residual disease in neuroblastoma.

The first and most promising retinoid, fenretinide (4HPR, modified all-trans retinoic acid), is able to inhibit growth and induce apoptosis [64]. In animal models, fenretinide prevented chemically induced cancers of the breast, prostate, bladder and skin; as well the combination of fenretinide with tamoxifen improved these results. This retinoid induces apoptosis by generating reactive oxygen species (ROS) and lipid second messengers in at least 10 cancer cell lines [65]. Notably, the effect of fenretinide occurs either in a dependent- or independentRAR- $\beta$ manner, according to the cell type and model analyzed. Fenretinide has apoptotic activity through Nur77 (an orphan nuclear receptor and immediate-early gene that regulates cellular proliferation, apoptosis, inflammation, and glucose metabolism). Two other synthetic retinoids that act as well through Nur77 are AHPN or CD437 (A retinoid-related molecule 6-[3-(1-adamantlyl)-4-hydroxyphenyl]-2-naphthalenecarboxylic acid) and its analog 3-Cl-AHPC ((E)-4-[3-(1-adamantlyl)-4-hydroxyphenyl]-3-chlorocinnamic acid). AHPN activates JNK in breast and prostate cancer cells, which is associated with Akt activity inhibition.

In several types of cancer cells the RAR- $\beta$ may play a critical role in slowing cancer progression. Some examples include as follows, breast, lung, ovarian and prostate cancers, as well as neuroblastoma, renal cell carcinoma, pancreatic, liver and head and neck cancers. The RAR- $\beta 2$ isoform is the most abundant and inducible form of retinoic acid receptor; it has tumor suppressor activity. Meanwhile, the RAR- $\beta 4$ has oncogenic activity. The RAR- $\beta$ up-regulation is associated with a good response to retinoids in patients with premalignant oral lesions [2]. The levels of the RAR- $\beta$ showed an increase in patients with renal cancer who responded to therapy with 13-cis-RA and interferon $\gamma$; 13 -cis-retinoic acid also up-regulated RAR- $\beta$ expression in premalignant lung lesions [10].

The somatic translocation between chromosomes 15 and 17 fuses the promyelocytic leukemia gene (PML) with the RAR- $\alpha$ gene forming a fusion protein (PML-RAR $\alpha$ ), containing the RAR- $\alpha$ ligand-binding domain (LBD). Resulting in the clinical manifestation of acute promyelocytic leukemia (APL). The combination of alltrans retinoic acid (ATRA) with anthracyclines recovers 70\% - 80\% of APL patients [66].

On the contrary, in breast cancer, the retinoid acts as an early stage inhibitor of tumor progression but appears to have no effect when the tumor becomes more aggressive [67] [68]. Through animal models the study of the mammary gland has shown that the RARs are differentially distributed, for example during lactation all RAR and RXR subtypes are expressed, however, normally only RAR- $\alpha$ and RXR- $\alpha$ are present [69]. Some breast cancer cell lines that are either hormone-dependent or -independent have shown the same expression pattern for RAR- $\alpha$, RAR- $\gamma$, RXR- $\alpha$ and RXR- $\beta$. Growth inhibition of breast cancer cells by RA has been associated with induction of the expression of the RAR- $\beta$. Loss or lack of RAR- $\beta$ may account for the decreased treatment efficacy of retinoids in patients with advanced breast tumors. In a rat model of mammary gland, carcinoma 9-cisRA and bexarotene (RXR-selective agonist) appeared superior to ATRA as a chemopreventive compound. The combination therapy of tamoxifen and fenretinide is an active regimen in metastatic breast cancer as well as in patients with progression of disease after tamoxifen treatment (review in [2]). Retinoids do not require estrogen receptors for their action, as they alterneoplastic transformation in estrogen-negative cells. Interestingly, retinoids and rexinoids seem to be more active in estrogen-positive than in estrogen-negative precancerous tissue. Retinoids probably promote breast cancer cells apoptosis through RAR- $\beta[70]$.

\section{Therapies Based on Retinoids in Lung Cancer}

Lung cancer causes the highest death rate of any cancer, with 1.38 million deaths annually $(18.2 \%$ of world cancer deaths). At diagnosis about $80 \%$ - $85 \%$ of patients are in clinical stages IIIb and IV, with 5-year survival rates below 15\%. Despite major advances in lung cancer treatment, median survival in patients with metastasic 
disease is between 12 - 14 months, and response rates range between $20 \%$ - 40\%. Due to the poor prognosis and low response rates to treatment, several non-cytotoxic agents such as retinoic acid and its derivates have been evaluated as chemopreventive and treatment agents.

The first studies used high-dose vitamin A's adjuvant effect, 307 NSCLC patients after curative surgery that were randomly assigned to either a prescribed retinol palmitate administration group (300,000 IU orally daily for 12 months) or a control group without treatment. Daily oral administration of high-dose vitamin A was effective in reducing the number of new primary tumors related to tobacco consumption. Treatment improved the disease-free interval in patients with curatively resected stage I lung cancer, with a median follow-up of 46 months; the number of patients with either recurrence or new primary tumors was $37 \%$ in the treated arm and $48 \%$ in the control arm [71].

Bexarotene, a synthetic RXR agonist, has an antiproliferative activity in preclinical in vitro and in vivo models [72]. The role of bexarotene has been evaluated in advanced NSCLC in two phase I studies in which it was well tolerated and showed retinoid-characteristic toxicities, such as leukopenia, hypertriglyceridemia, and hypercalcemia. In addition, targeting was able to delay tumor progression in NSCLC as well in other tumors [73] [74]. Some phase I/II trials determined the maximum-tolerated dose of bexarotene in combination with vinorelbine or cisplatin in patients with NSCLC. The most common adverse events were hyperlipidemia, leukopenia, nausea, vomiting, pneumonia, dyspnea, anemia, and asthenia. Encouraging results with acceptable response rates and association with better survival rates were observed with this combination [75]. The role of bexarotene in advanced NSCLC was evaluated in two phase III trials (SPIRIT I and SPIRIT II). In the first one, 623 patients with stage IIIB and pleural effusion or stage IV NSCLC were randomly assigned to either open-label bexarotene $400 \mathrm{mg} / \mathrm{m}^{2} /$ day with cisplatin/vinorelbine or to cisplatin/vinorelbine alone. No significant differences were observed between the bexarotene group and control group, regarding PFS (4.3 vs 5.0 months, $p=0.095)$ and overall survival (8.7 vs 9.9 months, $p=0.3$ ). The response rate was higher in the control group compared to the bexarotene group (24.4\% vs $16.7 \%, p=0.0224)$. A subset analysis of survival revealed no significant differences regarding sex, histology, stage, prior weight loss, ECOG or smoking status. However, approximately 32\% of the patients in the bexarotene arm developed hypertrigly ceridemia grade 3/4 according to the National Cancer Institute Criteria (serum triglyceride increases ( $\geq 5 \times$ the upper limit of normal), and the subgroup overall survival was significantly bettercompared to the control arm (12.3 vs 9.9 months, $p=0.087)$ [76]. In the SPIRIT II trial, a total of 612 patients with stage IIIB disease and pleural effusion or stage IV NSCLC were randomly assigned to bexarotene $400 \mathrm{mg} / \mathrm{m}^{2} /$ day combined with carboplatin plus paclitaxel, or carboplatin and paclitaxel alone. No significant differences were observed between the bexarotene group and the control groupregarding PFS (4.1 vs 4.9 months, $p=0.061$ ), overall survival (8.5 vs 9.2 months, $p=0.2$ ) or response rate (19.3\% vs $23.5 \% p=0.24)$. Furtherly, there were no differences regarding sex, histology, stage, prior weight loss, ECOG or smoking status; however, as in the SPIRIT I study, around $40 \%$ of patients in the bexarotene arm developed grade 3/4 hypertriglyceridemia, and the subgroup overall survival was better (12.4 vs 9.2 months, $p=0.014)$ [77]. From these studies the obtained conclusions showed that the addition of bexarotene to cisplatin-based chemotherapy did not improve overall survival compared with chemotherapy alone. However and most importantly, patients who developed grade 3/4 hypertriglyceridemia with bexarotene had better overall survival. The identification in prospective studies of predictive biomarkers for patients who could benefit from treatment with bexarotene are warranted [76] [77].

Accordingly, the role of ATRA has been extensively evaluated. In a phase II study, patients with unresectable locally advanced, or metastatic lung cancer were treated with ATRA $150 \mathrm{mg} / \mathrm{m}^{2} /$ day and IFN- $\alpha$ in combination. Some of the observed adverse effects in patients with radiological and clinical response after 8 weeks of treatment included grade I/II dermatitis and grade moderate/severe hypertrigly ceridemia [78]. Another phase II trial in which twenty-eight patients with metastatic NSCLC were treated with oral ATRA, showed mild toxicities including cutaneous effects and a significant number of patients with elevation of hepatic transaminases or hyperlipidemia. Overall two patients achieved partial response, one had a mixed response, and the median survival was 7 months. The results of this study evidenced that ATRA has minimal activity when used as a single agent in NSCLC treatment [79].

The retinoids have been exhibited as promising chemotherapeutic agents in several studies that tested the combination of two retinoids: tretinoin, $50 \mathrm{mg}$ twice-a-day for 4 days, and oral bexarotene, 375 mg once-a-day for 4 days, together with platin, docetaxel, and a brief course of capecitabine. The $71 \%$ of patients achieved partial response and patients presented with common retinoid side effects [80]. The administration of tretinoin on 
an intermittent dosing schedule to prevent decreased bioavailability was reported in patients taking protracted continuous treatment with tretinoin and other retinoids.

Other study used an interrupted dosing schedule of ATRA combined with cisplatin-VP 16chemotherapy, as treatment for stage IIIB and IV NSCLC patients. Ten patients had partial responses and four had minor responses. Neutropenia was the most common acute toxicity and median survival was 25.5 weeks. According to the authors, this regimen given with drug holiday and chemotherapy has a significant activity and good tolerance in advanced NSCLC [81].

In other phase II study, one hundred and seven patients with advanced NSCLC were included in arandomized design to compare ATRA ( $20 \mathrm{mg} / \mathrm{m}^{2} /$ day) in combination with paclitaxel plus cisplatin versus placebo plus paclitaxel and cisplatin. The ATRA group versus the placebo group had a higher response rate $(55.8 \%$ vs $25.4 \%, p$ $=0.001$ ), a longer PFS (8.9 versus 6.0 months; $p=0.008$ ), and overall survival ( 9.6 versus 23.5 months, $\mathrm{HR}=$ 0.52 ; $95 \%$ CI, 0.29 to $0.9 ; p=0.020$ ) [82]. Seventy-five percent of the experimental group patients with positive RAR- $\beta 2$ IHC expression presented response to treatment, suggesting that a subgroup of patients could have a greater benefit by adding ATRA to the regimen [82].

Fenretinide [N-(4-hydroxyphenyl) retinamide, 4-HPR], a synthetic retinoid, has been tested in preclinical trials that have shown significant cytotoxic activity through the induction of apoptosis in a variety of types of small cell and NSCLC [83]. The fenretinide has been evaluated as a therapeutic agent in patients with small cell lung cancer (SCLC). Its treatment resulted in disease stabilization in $24 \%$ of evaluable patients with recurrent SCLC, also, the median of survival was of 25 weeks. Treatment was well tolerated with mild, transient changes in night vision as the only common toxicity without complete or partial responses identified, suggesting that fenretinide is inactive as a single agent in the treatment of SCLC [84]. A phase II trial evaluated the modulation of Bcl-2 with 13-CRA and IFN- $\alpha$ in combination with paclitaxel in patients with recurrent SCLC. The addition of 13-CRA and IFN- $\alpha$ to paclitaxel was no better than the historic use of paclitaxel alone, and there was no association between Bcl-2 levels and response rate or survival in this cohort of patients. Furthermore, the toxicity appeared greater than paclitaxel as a single agent [85]. The incidence of abnormalities in the RAR- $\beta$ expression on bronchial cells of smokers and the capacity of re-induction of this receptor by 13-cis-RA treatment were analyzed in a study. Forty-four eligible patients with diminished RAR- $\beta$ expression were double-blind randomized to receive either placebo or 13-CRA (30 mg orally, daily) for 6 months. The results showed that the RAR- $\beta$ expression is frequently decreased in the bronchial epithelium of smokers and it was up-regulated when they were treated with 13-cis-RA [56].

Some studies suggest that retinoid supplementation might reduce tumor occurrence and mortality in nonsmokers, and might even be beneficial for former smokers [86]-[88]. However, other studies have shown a risk of lung cancer development in current smokers [86] [89] [90]. The Carotene and Retinol Efficacy Trial (CARET) showed that patients with smoking history had an increased incidence of lung cancer. Other studies did not show benefit as well in decreasing the incidence of lung cancer [86]-[88]. Active smokers showed a higher incidence of recurrence and mortality when treated with retinoids [91]. Other studies showed as well that smokers who received $\beta$-carotene presented a higher incidence of lung cancer [71] [92]. These results suggest that retinoids may facilities ability carcinogenic compounds in cigarettes to activate cancer genes, increasing the risk of lung cancer development (Table 1).

\section{Disadvantages of Retinoid Treatment over Lung Cancer}

Retinoids have been used as adjuvants in the treatment of diverse cancers, however, some serious adverse events have been reported such as cheilitis, xerosis, skin peeling, photosensitivity, alopecia, headaches, and dyslipidemia [93]. These effects have been related with the natural retinoids binding site including the RAR receptors, for these reasons some synthetic selective RXR retinoids have been developed to avoid this adverse event. In contrast, rexinoids are associated with mild to moderate skin toxicity [94].

The 13-cis-RA has been used as treatment in diverse trials alone or in combination with other drugs. Common side effects observed in the EUROSCAN trial were dryness, desquamation, itching, bleeding, and hair loss [95]. A phase I study using 13-cis-retinoic ranging from 20 to $120 \mathrm{mg} / \mathrm{m}^{2}$ to treat head and neck malignancies, showed that doses greater than $60 \mathrm{mg} / \mathrm{m}^{2}$ induced intense headaches, urethritis, desquamative dermatitis, vertigo, and ataxia. These side effects increase when there is a combination with chemotherapy agents [96] [97]. Besides, the combination of ATRA/IFN-a or 13cRA/IFN-a has shown major grade 3 and 4 toxicities, as follows. Grade 3 malaise and fatigue were nearly uniformly observed, and were disabling in $26 \%$ of patients on 13cRA/IFN-a and 
Table 1. Lung cancer treatment based on Vitamin A. Some clinical trials of the use of Vitamin A as treatment of lung cancer.

\begin{tabular}{|c|c|c|c|c|c|c|}
\hline Retinoid & Dosis & $\begin{array}{l}\text { Combination } \\
\text { with other drugs }\end{array}$ & $\begin{array}{l}\text { Stage of } \\
\text { disease }\end{array}$ & Outcomes & $\begin{array}{c}\text { Adverse } \\
\text { event }\end{array}$ & Reference \\
\hline \multirow[t]{2}{*}{$\begin{array}{l}\text { Retinyl } \\
\text { palmitate }\end{array}$} & $300,000 \mathrm{IU}$ & & $\begin{array}{l}\text { Stage I of } \\
\text { lung cancer }\end{array}$ & $\begin{array}{l}\text { Improve disease } \\
\text { free interval. } \\
\text { PFS } 46 \text { months }\end{array}$ & $\begin{array}{c}\text { Skin dryness } \\
\text { and desquamation }\end{array}$ & {$[71]$} \\
\hline & $50,000 \mathrm{IU}$ & IFN- $\beta$, 5 FU, Cisplatin & $\begin{array}{l}\text { Stage IIB } \\
\text { and IV }\end{array}$ & OS 9.1 months & $\begin{array}{l}\text { Cutaneous symptoms. } \\
\text { Squamous histology, } \\
\text { with a substantial toxicity. }\end{array}$ & [109] \\
\hline \multirow[t]{5}{*}{ Bexarotene } & $400 \mathrm{mg} / \mathrm{m}^{2} /$ day & $\begin{array}{l}\text { Vinorelbine } \\
\text { cisplatin }\end{array}$ & $\begin{array}{l}\text { Stage IIB } \\
\text { and IV }\end{array}$ & $\begin{array}{l}\text { PFS } 4.3 \text { months } \\
\text { OS } 8.7 \text { months }\end{array}$ & $\begin{array}{c}\text { Hypertriglyceridemia, } \\
\text { leukopenia, dermatitis } \\
\text { grade } 3 / 4\end{array}$ & {$[75]$} \\
\hline & $300 \mathrm{mg} / \mathrm{m}^{2} /$ day & & $\begin{array}{l}\text { Stage I and } \\
\text { II }\end{array}$ & $\begin{array}{c}\text { Modify the expression } \\
\text { of cyclin D3, } \\
\text { EGFR, and Ki-67. }\end{array}$ & & [110] \\
\hline & $400 \mathrm{mg} / \mathrm{m}^{2} /$ day & Paclitaxel carboplatin & & $\begin{array}{l}\text { Plasma concentrations } \\
\text { of bexarotene } \\
\text { increased by } 80 \% \\
\text { in the presence of } \\
\text { paclitaxel-carboplatin }\end{array}$ & $\begin{array}{c}\text { Hypertriglyceridemia } \\
\text { hypercholesterolemia } \\
\text { and hypothyroidism } \\
\text { grade } 2 / 3\end{array}$ & [111] \\
\hline & $400 \mathrm{mg} / \mathrm{m}^{2}$ & $\begin{array}{l}\text { Carboplatin } \\
\text { gemcitabine }\end{array}$ & $\begin{array}{l}\text { Stage IIB } \\
\text { and IV }\end{array}$ & OS 12.7 months & Hypertriglyceridemia & [112] \\
\hline & $400 \mathrm{mg} / \mathrm{m}^{2} /$ day & $\begin{array}{l}\text { Paclitaxel-carboplatin or } \\
\text { cisplatin-vinorelbine with } \\
\text { atorvastatin or fenofibrate }\end{array}$ & $\begin{array}{l}\text { Stage IIIB } \\
\text { and IV }\end{array}$ & $\begin{array}{l}\text { Concentration-time } \\
\text { curve }\end{array}$ & $\begin{array}{c}\text { Hypertriglyceridemia } \\
\text { and hypercholesterolemia } \\
\text { grade } 3 / 4\end{array}$ & [113] \\
\hline \multirow{4}{*}{$\begin{array}{l}\text { All-trans } \\
\text { retinoic } \\
\text { acid } \\
\text { (ATRA) }\end{array}$} & $150 \mathrm{mg} / \mathrm{m}^{2} /$ day & IFN- $\alpha$ & & OS 8 months & $\begin{array}{c}\text { Dermatitis grade I/II } \\
\text { hypertriglyceridemia 3/4 }\end{array}$ & [114] \\
\hline & $100 \mathrm{mg} / \mathrm{m}^{2} /$ day & $\begin{array}{l}\text { Bexarotene, } \\
\text { docetaxel } \\
\text { capecitabine }\end{array}$ & $\begin{array}{l}\text { Stage IIB } \\
\text { and IV }\end{array}$ & OS 19 months & & [115] \\
\hline & & $\begin{array}{l}\text { Somatostatinmelatonin, } \\
\text { vitamin } \mathrm{D} \text {, bromocriptine, } \\
\text { and cyclophosphamide }\end{array}$ & $\begin{array}{l}\text { Stage IIB } \\
\text { and IV }\end{array}$ & OS 12.9 months & $\begin{array}{l}\text { Diarrhea, nausea, } \\
\text { and drowsiness }\end{array}$ & [116] \\
\hline & $20 \mathrm{mg} / \mathrm{m}^{2} /$ day & $\begin{array}{l}\text { Paclitaxel } \\
\text { cisplatin }\end{array}$ & $\begin{array}{l}\text { Stage IIB } \\
\text { and IV }\end{array}$ & $\begin{array}{l}\text { PFS } 8.9 \text { months } \\
\text { OS } 9.6 \text { months }\end{array}$ & Hypertriglyceridemia & [82] \\
\hline \multirow[t]{4}{*}{ 13-cis-RA } & $1 \mathrm{mg} / \mathrm{kg}$ & 9-cis-RAalpha-tocopherol & $\begin{array}{l}\text { Former } \\
\text { smokers }\end{array}$ & $\begin{array}{l}\text { Reduced bronchial } \\
\text { epithelial cell } \\
\text { proliferation }\end{array}$ & & [117] \\
\hline & $\begin{array}{l}1 \mathrm{mg} / \mathrm{kg} \text { orally } \\
\text { on days } 1 \text { and } 2\end{array}$ & $\begin{array}{l}\text { Interferon alpha, } \\
\text { paclitaxel }\end{array}$ & $\begin{array}{l}\text { Small } \\
\text { cell lung } \\
\text { cancer }\end{array}$ & $\begin{array}{l}\text { Median OS } \\
6.2 \text { months } \\
\text { PFS } 2.0\end{array}$ & $\begin{array}{c}\text { Cytopenias, leukopenia, } \\
\text { neutropenia } \\
\text { fatigue and } \\
\text { hypertriglyceridemia } \\
\text { grade } 3\end{array}$ & [118] \\
\hline & $0.5 \mathrm{mg} / \mathrm{kg}$ & Interleukin 2 & Solid tumor & OS 13.7 months & $\begin{array}{c}\text { Consisting of fever, } \\
\text { fatigue, } \\
\text { thrombocytopenia, } \\
\text { mucositis, and local } \\
\text { cutaneous reaction }\end{array}$ & [119] \\
\hline & 50 mg/day & Tocopherol & $\begin{array}{c}\text { Adult } \\
\text { subjects at } \\
\text { high risk for } \\
\text { lung cancer }\end{array}$ & & $\begin{array}{l}\text { Skin toxicities, elevated } \\
\text { uric acid, triglycerides, } \\
\text { and cholesterol }\end{array}$ & [120] \\
\hline
\end{tabular}

Abbreviation: IFN- $\beta$ : Interferon Beta; 5 FU; 5-Fluorouracil; OS: Overall survival; PFS: Progression free survival; EGFR: Epidermal Growth Factor; IFN- $\alpha$ : Interferon alpha; pERGFR, and Ki-67: Ki-67 protein. 
in $21 \%$ of patients on ATRA/IFN-a. Additional grade 4toxicities within both treatment arms included nausea and vomiting, anemia was observed. Although myalgias and arthralgias, mucocutaneous reactions, granulocytopenia, leukopenia, thrombocytopenia, elevated liver functions, vision loss, hyperlipidemia, and hypertriglyceridemia were registered, these adverse events were present in a minor proportion [98]. In addition, in a study comparing the treatment of 13cRA with combined Betacarotene plus retinyl palmitate versus retinyl palmitate alone, the main adverse events observed were cheilitis, conjunctivitis, and skin reactions. The reactions were significantly more common in low-doses of 13cRA and it was not well tolerated for long-term in oral cancer [97]. In a phase II study to treat basal-cell carcinomas, the combination of alpha-IFN with 13cRA acid showed mild toxicity, which was reversible in all cases; major side effects observed included fever, nausea, skin erythema, hypertriglyceridemia and hypercholesteremia [99].

The retinoid that has shown a worse adverse event profile for lung cancer treatment was betacarotene. In a cohort of patients the use of betacarotene resulted in unexpected significantly higher incidence and mortality of lung cancer. Despite a lack of safety concerns in a second unplanned interim analysis, the modified the protocol in 1996 after CARET1 showed a 18\% increase in lung cancer mortality in the Betacarotene plus retinyl palmitate arm (v placebo), higher than the increased mortality with betacarotene in the Alpha-Tocopherol and BetaCarotene study [89].

Bexarotene is a retinoid that selectively activates retinoid $\mathrm{X}$ receptors. Patients treated with bexarotene present increases in total cholesterol and low-density lipoprotein cholesterol without significant changes in highdensity lipoprotein cholesterol and apolipoprotein, and the most common side effects reported in the literature are related with hyperlipidaemia and secondary hypothyroidism [100]-[102]. These data suggest that treatment with the selective RXR ligand bexarotene causes alterations primarily in cholesterol metabolism, this elevation is due to transactivation by LXR/RXR heterodimers of SREBP-1c (Sterol Regulatory element-binding proteins), a master transcriptional regulator of genes involved in cholesterol biosynthesis [94].

Hyperlipidaemia is observed in patients taking at least $300 \mathrm{mg} / \mathrm{m}^{2} /$ day of bexarotene for cutaneous T-cell lymphomas [103]. Bexarotene at doses of $400 \mathrm{mg} / \mathrm{kg}$ was well tolerated, and the most frequent toxicities were mild hypertriglyceridemia and skin rash [104]. The combination of bexarotene with cisplatin and vinorelbine showed hyperlipemia, hypothyroidism, dyspnea, and headache when compared with the group without bexarotene [76]. Bexarotene-treated patients with grade 3/4 hypertriglyceridemia who received the most benefit included those who were male, and smokers. The incidence and severity of most adverse events were similar between arms, although hyperlipidemia, neutropenia, fatigue, leukopenia, arthralgia, and diarrhea were more frequent in the bexarotene arm [75] [105] [106]. Levels of hypertriglyceridemia and elevated liver enzymes were reversible upon dose reduction or cessation. Less common side effects included mild gastrointestinal symptoms, headaches, myalgia/arthralgia, and fatigue. Hematological toxicities occurred in trials combining retinoids with chemotherapy, however, these were not common in trials of retinoids alone, suggesting chemotherapy as the causative agent [56].

The most frequent symptoms observed in patients of cervical intraepithelial neoplasia that were treated with high-dose 9-cis-RA (50 mg) or low-dose of 9-cis-RA (25 mg) were, as follows: headache (60\%), fatigue (31\%), and nausea (25\%). In addition, an elevation in median serum triglycerides and significant reduction in median high-density lipoprotein (HDL) levels were found in both, low and high, doses of 9-cis-RA treated patients [107]. In former smokers, after 3 months of treatment with 9-cis-RA the serum level of Insulin-like growth factor 1 (IGF-I) decreased as well as the molar ratio of IGF-I to insulin-like growth factor binding protein 3 (IGFBP-3), meanwhile the serum level of IGFBP-3 increased; the latter suggesting this molecules as biomarkers of 9-cis-RA treatment [108].

\section{Conclusion}

The RARs are important functional regulators in most of the epithelial cells. Recent evidence suggests that the lack of nuclear RARs may play a critical role in lung carcinogenesis. The RAR expression tends to decrease as cancer progresses, suggesting a pivotal role. Alterations in the RARs and RXRs during lung cancer are important in understanding the role of retinoids and rexinoids as chemoprevention and chemotherapy agents. The expression of several of these receptors is modified during differential stages of the disease, and could be potential biomarkers for the possible response to chemotherapy in several different malignancies. Specifically, in NSCLC with advanced disease, predictive biomarkers are warranted to determine the benefit of bexarotene or ATRA usage. 


\section{References}

[1] McKenna, N.J. (2012) EMBO Retinoids 2011: Mechanisms, Biology and Pathology of Signaling by Retinoic Acid and Retinoic Acid Receptors. Nuclear Receptor Signaling, 10, e003.

[2] Bushue, N. and Wan, Y.J. (2010) Retinoid Pathway and Cancer Therapeutics. Advanced Drug Delivery Reviews, 62, 1285-1298. http://dx.doi.org/10.1016/j.addr.2010.07.003

[3] Schug, T.T., Berry, D.C., Shaw, N.S., Travis, S.N. and Noy, N. (2007) Opposing Effects of Retinoic Acid on Cell Growth Result from Alternate Activation of Two Different Nuclear Receptors. Cell, 129, 723-733. http://dx.doi.org/10.1016/j.cell.2007.02.050

[4] Germain, P., Chambon, P., Eichele, G., Evans, R.M., Lazar, M.A., Leid, M., De Lera, A.R., Lotan, R., Mangelsdorf, D.J. and Gronemeyer, H. (2006) International Union of Pharmacology. LX. Retinoic Acid Receptors. Pharmacological Reviews, 58, 712-725. http://dx.doi.org/10.1124/pr.58.4.4

[5] Shaw, N., Elholm, M. and Noy, N. (2003) Retinoic Acid Is a High Affinity Selective Ligand for the Peroxisome Proliferator-Activated Receptor Beta/Delta. The Journal of Biological Chemistry, 278, 41589-41592. http://dx.doi.org/10.1074/jbc.C300368200

[6] Berry, D.C. and Noy, N. (2009) All-Trans-Retinoic Acid Represses Obesity and Insulin Resistance by Activating Both Peroxisome Proliferation-Activated Receptor Beta/Delta and Retinoic Acid Receptor. Molecular and Cellular Biology, 29, 3286-3296. http://dx.doi.org/10.1128/MCB.01742-08

[7] Jozan, S., Paute S., Courtade-Saidi, M., Julie, S., Vidal, S., Bugat, R. and Valette, A. (2002) All Trans Retinoic Acid Enhances CDDP-Induced Apoptosis: Modulation of the CDDP Effect on Cell Cycle Progression. International Journal of Oncology, 20, 1289-1295. http://dx.doi.org/10.3892/ijo.20.6.1289

[8] Yu, S., Levi, L., Siegel, R. and Noy, N. (2012) Retinoic Acid Induces Neurogenesis by Activating Both Retinoic Acid Receptors (RARs) and Peroxisome Proliferator-Activated Receptor Beta/Delta (PPARbeta/Delta). The Journal of Biological Chemistry, 287, 42195-42205. http://dx.doi.org/10.1074/jbc.M112.410381

[9] Wein, T.H. and Albers, J.W. (2001) Diabetic Neuropathies. Physical Medicine Rehabilitation Clinics of North America, 12, 307-320.

[10] Zhelyaznik, N. and Mey, J. (2006) Regulation of Retinoic Acid Receptors Alpha, Beta and Retinoid X Receptor Alpha after Sciatic Nerve Injury. Neuroscience, 141, 1761-1774. http://dx.doi.org/10.1016/j.neuroscience.2006.05.021

[11] Smith, A.G. and Singleton, J.R. (2013) Obesity and Hyperlipidemia Are Risk Factors for Early Diabetic Neuropathy. Journal of Diabetes and Its Complications, 27, 436-442. http://dx.doi.org/10.1016/j.jdiacomp.2013.04.003

[12] Niles, R.M. (2007) Biomarker and Animal Models for Assessment of Retinoid Efficacy in Cancer Chemoprevention. Acta Pharmacologica Sinica, 28, 1383-1391. http://dx.doi.org/10.1111/j.1745-7254.2007.00685.X

[13] Heyman, R.A., Mangelsdorf, D.J., Dyck, J.A., Stein, R.B., Eichele, G., Evans, R.M. and Thaller, C. (1992) 9-cis Retinoic Acid Is a High Affinity Ligand for the Retinoid X Receptor. Cell, 68, 397-406. http://dx.doi.org/10.1016/0092-8674(92)90479-V

[14] Ondrey, F. (2009) Peroxisome Proliferator-Activated Receptor Gamma Pathway Targeting in Carcinogenesis: Implications for Chemoprevention. Clinical Cancer Research, 15, 2-8. http://dx.doi.org/10.1158/1078-0432.CCR-08-0326

[15] de The, H., del Mar Vivanco-Ruiz, M., Tiollais, P., Stunnenberg, H. and Dejean, A. (1990) Identification of a Retinoic Acid Responsive Element in the Retinoic Acid Receptor Beta Gene. Nature, 343, 177-180. http://dx.doi.org/10.1038/343177a0

[16] Leid, M., Kastner, P. and Chambon, P. (1992) Multiplicity Generates Diversity in the Retinoic Acid Signalling Pathways. Trends in Biochemical Sciences, 17, 427-433. http://dx.doi.org/10.1016/0968-0004(92)90014-Z

[17] de Lera, A.R., Bourguet, W., Altucci, L. and Gronemeyer, H. (2007) Design of Selective Nuclear Receptor Modulators: RAR and RXR as a Case Study. Nature Reviews Drug Discovery, 6, 811-820. http://dx.doi.org/10.1038/nrd2398

[18] Fujita, A. and Mitsuhashi, T. (1999) Differential Regulation of Ligand-Dependent and Ligand-Independent Functions of the Mouse Retinoid X Receptor Beta by Alternative Splicing. Biochemical and Biophysical Research Communications, 255, 625-630. http://dx.doi.org/10.1006/bbrc.1999.0243

[19] Lefebvre, P., Benomar, Y. and Staels, B. (2010) Retinoid X Receptors: Common Heterodimerization Partners with Distinct Functions. Trends in Endocrinology Metabolism, 21, 676-683. http://dx.doi.org/10.1016/j.tem.2010.06.009

[20] Halifeoglu, I., Canatan, H., Ustundag, B., Ilhan, N. and Inanc, F. (2000) Effect of Thinner Inhalation on Lipid Peroxidation and Some Antioxidant Enzymes of People Working with Paint Thinner. Cell Biochemistry and Function, 18, 263-267. http://dx.doi.org/10.1002/1099-0844(200012)18:4<263::AID-CBF882>3.0.CO;2-1

[21] Nagata, T., Weiss, E.H., Abe, K., Kitagawa, K., Ando, A., Yara-Kikuti, Y., Seldin, M.F., Ozato, K., Inoko, H. and Taketo, M. (1995) Physical Mapping of the Retinoid X Receptor B Gene in Mouse and Human. Immunogenetics, 41, 
83-90. http://dx.doi.org/10.1007/BF00182317

[22] Massaro, G.D., Massaro, D. and Chambon, P. (2003) Retinoic Acid Receptor-Alpha Regulates Pulmonary Alveolus Formation in Mice After, but Not During, Perinatal Period. American Journal of Physiology-Lung Cellular and Molecular Physiology, 284, L431-L433. http://dx.doi.org/10.1152/ajplung.00245.2002

[23] Picard, E., Seguin, C., Monhoven, N., Rochette-Egly, C., Siat, J., Borrelly, J., Martinet, Y., Martinet, N. and Vignaud, J.M. (1999) Expression of Retinoid Receptor Genes and Proteins in Non-Small-Cell Lung Cancer. Journal of the National Cancer Institute, 91, 1059-1066. http://dx.doi.org/10.1093/jnci/91.12.1059

[24] Kastner, P., et al. (1997) Genetic Evidence That the Retinoid Signal Is Transduced by Heterodimeric RXR/RAR Functional Units during Mouse Development. Development, 124, 313-326.

[25] Mendelsohn, C., et al. (1994) Function of the Retinoic Acid Receptors (RARs) during Development (II). Multiple Abnormalities at Various Stages of Organogenesis in RAR Double Mutants. Development, 120, 2749-2771.

[26] Lohnes, D., Mark, M., Mendelsohn, C., Dollé, P., Decimo, D., LeMeur, M., Dierich, A., Gorry, P. and Chambon, P. (1995) Developmental Roles of the Retinoic Acid Receptors. The Journal of Steroid Biochemistry and Molecular Biology, 53, 475-486. http://dx.doi.org/10.1016/0960-0760(95)00094-G

[27] Luo, J.M., Pasceri, P., Conlon, R.A., Rossant, J. and Giguère, V. (1995) Mice Lacking All Isoforms of Retinoic Acid Receptor Beta Develop Normally and Are Susceptible to the Teratogenic Effects of Retinoic Acid. Mechanisms of Development, 53, 61-71. http://dx.doi.org/10.1016/0925-4773(95)00424-6

[28] Ghyselinck, N.B., et al. (1997) Role of the Retinoic Acid Receptor Beta (RARbeta) during Mouse Development. The International Journal of Developmental Biology, 41, 425-447.

[29] Mollard, R., et al. (2000) Stage-Dependent Responses of the Developing Lung to Retinoic Acid Signaling. The International Journal of Developmental Biology, 44, 457-462.

[30] Dollé, P., Fraulob, V., Kastner, P. and Chambon, P. (1994) Developmental Expression of Murine Retinoid X Receptor (RXR) Genes. Mechanisms of Development, 45, 91-104. http://dx.doi.org/10.1016/0925-4773(94)90023-X

[31] Dolle, P., et al. (1990) Retinoic Acid Receptors and Cellular Retinoid Binding Proteins. I. A Systematic Study of Their Differential Pattern of Transcription during Mouse Organogenesis. Development, 110, 1133-1151.

[32] Hind, M., Corcoran, J. and Maden, M. (2002) Temporal/Spatial Expression of Retinoid Binding Proteins and RAR Isoforms in the Postnatal Lung. American Journal of Physiology-Lung Cellular and Molecular Physiology, 282, L468L476. http://dx.doi.org/10.1152/ajplung.00196.2001

[33] McGowan, S., Jackson, S.K., Jenkins-Moore, M., Dai, H.-H., Chambon, P. and Snyder, J.M. (2000) Mice Bearing Deletions of Retinoic Acid Receptors Demonstrate Reduced Lung Elastin and Alveolar Numbers. American Journal of Respiratory Cell and Molecular Biology, 23, 162-167. http://dx.doi.org/10.1165/ajrcmb.23.2.3904

[34] Druilhe, A., Zahm, J.-M., Benayoun, L., El Mehdi, D., Grandsaigne, M., Dombret, M.-C., Mosnier, I., Feger, B., Depondt, J., Aubier, M. and Pretolani, M. (2008) Epithelium Expression and Function of Retinoid Receptors in Asthma. American Journal of Respiratory Cell and Molecular Biology, 38, 276-282. http://dx.doi.org/10.1165/rcmb.2006-04530C

[35] Antczak, A., Migdalska-Sęk, M., Pastuszak-Lewandoska, D., Czarnecka, K., Nawrot, E., Domańska, D., Kordiak, J., Górski, P. and Brzeziańska, E. (2013) Significant Frequency of Allelic Imbalance in 3p Region Covering RARbeta and MLH1 Loci Seems to Be Essential in Molecular Non-Small Cell Lung Cancer Diagnosis. Medical Oncology, 30, 532. http://dx.doi.org/10.1007/s12032-013-0532-9

[36] Virmani, A.K., Rathi, A., Zochbauer-Muller, S., Sacchi, N., Fukuyama, Y., Bryant, D., Maitra, A., Heda, S., Fong, K.M., Thunnissen, F., Minna, J.D. and Gazdar, A.F. (2000) Promoter Methylation and Silencing of the Retinoic Acid Receptor-Beta Gene in Lung Carcinomas. Journal of the National Cancer Institute, 92, 1303-1307. http://dx.doi.org/10.1093/jnci/92.16.1303

[37] Lee, S.M., Lee, J.Y., Choi, J.E., Lee, S.Y., Park, J.Y. and Kim, D.S. (2010) Epigenetic Inactivation of Retinoid X Receptor Genes in Non-Small Cell Lung Cancer and the Relationship with Clinicopathologic Features. Cancer Genetics and Cytogenetics, 197, 39-45. http://dx.doi.org/10.1016/j.cancergencyto.2009.10.008

[38] Sun, J.Y., Xu, X., Liu, J.T., Liu, H., Fu, L. and Gu, L. (2011) Epigenetic Regulation of Retinoic Acid Receptor Beta2 Gene in the Initiation of Breast Cancer. Medical Oncology, 28, 1311-1318. http://dx.doi.org/10.1007/s12032-010-9685-y

[39] Jones, P.L., Jan , G.C., Wade P.A., Vermaak, D., Kass, S.U., Landsberger, N., Strouboulis, J. and Wolffe, A.P. (1998) Methylated DNA and MeCP2 Recruit Histone Deacetylase to Repress Transcription. Nature Genetics, 19, 187-191. http://dx.doi.org/10.1038/561

[40] Cameron, E.E., Bachman, K.E., Myöhänen, S., Herman, J.G. and Baylin, S.B. (1999) Synergy of Demethylation and Histone Deacetylase Inhibition in the Re-Expression of Genes Silenced in Cancer. Nature Genetics, 21, 103-107. http://dx.doi.org/10.1038/5047 
[41] Li, W., Deng, J., Wang, S.-S., Ma, L., Pei, J., Zeng, X.-X. and Tang, J.-X. (2014) Association of Methylation of the RAR-beta Gene with Cigarette Smoking in Non-Small Cell Lung Cancer with Southern-Central Chinese Population. Asian Pacific Journal of Cancer Prevention, 15, 10937-10941. http://dx.doi.org/10.7314/APJCP.2014.15.24.10937

[42] Kim, Y.J., Jin, D.H., Lee, B.B., Cho, E.Y., Han, J., Shim, Y.M. and Kim, D.-H. (2015) RARbeta2 Hypermethylation Is Associated with Poor Recurrence-Free Survival in Never-Smokers with Adenocarcinoma of the Lung. Clinical Epigenetics, 7, 32. http://dx.doi.org/10.1186/s13148-015-0066-4

[43] Kim, J.S., Lee, H., Kim, H., Shim, Y.M., Han, J., Park, J. and Kim, D.-H. (2004) Promoter Methylation of Retinoic Acid Receptor Beta 2 and the Development of Second Primary Lung Cancers in Non-Small-Cell Lung Cancer. Journal of Clinical Oncology, 22, 3443-3450. http://dx.doi.org/10.1200/JCO.2004.11.135

[44] Breitling, L.P., Yang, R.X., Korn, B., Burwinkel, B. and Brenner, H. (2011) Tobacco-Smoking-Related Differential DNA Methylation: 27K Discovery and Replication. The American Journal of Human Genetics, 88, 450-457. http://dx.doi.org/10.1016/j.ajhg.2011.03.003

[45] Scesnaite, A., Jarmalaite, S., Mutanen, P., Anttila, S., Nyberg, F., Benhamou, S., Boffetta, P. and Husgafvel-Pursiainen, K. (2012) Similar DNA Methylation Pattern in Lung Tumours from Smokers and Never-Smokers with Second-Hand Tobacco Smoke Exposure. Mutagenesis, 27, 423-429. http://dx.doi.org/10.1093/mutage/ger092

[46] Zeilinger, S., et al. (2013) Tobacco Smoking Leads to Extensive Genome-Wide Changes in DNA Methylation. PLoS ONE, 8, e63812. http://dx.doi.org/10.1371/journal.pone.0063812

[47] Tseng, R.-C., Chang, J.-W., Hsien, F.-J., Chang, Y.-H., Hsiao, C.-F., Chen, J.-T., Chen, C.-Y., Jou, Y.-S. and Wang, Y.-C. (2005) Genomewide Loss of Heterozygosity and Its Clinical Associations in Non Small Cell Lung Cancer. International Journal of Cancer, 117, 241-247. http://dx.doi.org/10.1002/ijc.21178

[48] Yoshino, I., Fukuyama, S., Kameyama, T., Shikada, Y., Oda, S., Maehara, Y. and Sugimachi, K. (2003) Detection of Loss of Heterozygosity by High-Resolution Fluorescent System in Non-Small Cell Lung Cancer: Association of Loss of Heterozygosity with Smoking and Tumor Progression. Chest, 123, 545-550. http://dx.doi.org/10.1378/chest.123.2.545

[49] Mao, L., Lee, J.S., Kurie, J.M., Fan, Y.H., Lippman, S.M., Broxson, A., Khuri, F.R., Hong, W.K., Lee, J.J., Yu, R., Ro, J.Y., Kemp, B.L., Morice, R.C., Walsh, G.L. and Hittelman, W.N. (1997) Clonal Genetic Alterations in the Lungs of Current and Former Smokers. Journal of the National Cancer Institute, 89, 857-862. http://dx.doi.org/10.1093/jnci/89.12.857

[50] Hirao, T., et al. (2001) Tobacco Smoke-Induced DNA Damage and an Early Age of Smoking Initiation Induce Chromosome Loss at 3p21 in Lung Cancer. Cancer Research, 61, 612-615.

[51] Brabender, J., Metzger, R., Salonga, D., Danenberg, K.D., Danenberg, P.V., Hölscher, A.H. and Schneider, P.M. (2005) Comprehensive Expression Analysis of Retinoic Acid Receptors and Retinoid X Receptors in Non-Small Cell Lung Cancer: Implications for Tumor Development and Prognosis. Carcinogenesis, 26, 525-530. http://dx.doi.org/10.1093/carcin/bgi006

[52] Corcoran, J. and Maden, M. (1999) Nerve Growth Factor Acts via Retinoic Acid Synthesis to Stimulate Neurite Outgrowth. Nature Neuroscience, 2, 307-308. http://dx.doi.org/10.1038/7214

[53] Corcoran, J., et al. (2000) The Role of Retinoic Acid Receptors in Neurite Outgrowth from Different Populations of Embryonic Mouse Dorsal Root Ganglia. Journal of Cell Science, 113, 2567-2574.

[54] Houle, B., Rochette-Egly, C. and Bradley, W.E. (1993) Tumor-Suppressive Effect of the Retinoic Acid Receptor Beta in Human Epidermoid Lung Cancer Cells. Proceedings of the National Academy of Sciences of the United States of America, 90, 985-989. http://dx.doi.org/10.1073/pnas.90.3.985

[55] Chang, Y.S., Chung, J.H., Shin, D.H., Chung, K.Y., Kim, Y.S., Chang, J., Kim, S.K. and Kim, S.K. (2004) Retinoic Acid Receptor-Beta Expression in Stage I Non-Small Cell Lung Cancer and Adjacent Normal Appearing Bronchial Epithelium. Yonsei Medical Journal, 45, 435-442. http://dx.doi.org/10.3349/ymj.2004.45.3.435

[56] Fritz, H., Kennedy, D., Fergusson, D., Fernandes, R., Doucette, S., Cooley, K., Seely, A., Sagar, S., Wong, R. and Seely, D. (2011) Vitamin A and Retinoid Derivatives for Lung Cancer: A Systematic Review and Meta Analysis. PLoS ONE, 6, e21107. http://dx.doi.org/10.1371/journal.pone.0021107

[57] Choi, E.J., Whang, Y.M., Kim, S.J., Kim, H.J. and Kim, Y.H. (2007) Combinational Treatment with Retinoic Acid Derivatives in Non-Small Cell Lung Carcinoma in Vitro. Journal of Korean Medical Science, 22, S52-S60. http://dx.doi.org/10.3346/jkms.2007.22.S.S52

[58] Anzano, M.A., et al. (1994) Prevention of Breast Cancer in the Rat with 9-cis-Retinoic Acid as a Single Agent and in Combination with Tamoxifen. Cancer Research, 54, 4614-4617.

[59] Christov, K.T., et al. (2002) 9-cis-Retinoic Acid but Not 4-(Hydroxyphenyl)Retinamide Inhibits Prostate Intraepithelial Neoplasia in Noble Rats. Cancer Research, 62, 5178-5182. 
[60] Elstner, E., Campbell, M.J., Munker, R., Shintaku, P., Binderup, L., Heber, D., Said, J. and Koeffler, H.P. (1999) Novel 20-epi-Vitamin $\mathrm{D}_{3}$ Analog Combined with 9-cis-Retinoic Acid Markedly Inhibits Colony Growth of Prostate Cancer Cells. The Prostate, 40, 141-149. http://dx.doi.org/10.1002/(SICI)1097-0045(19990801)40:3<141::AID-PROS1>3.0.CO;2-C

[61] Yamazaki, K., Shimizu, M., Okuno, M., Matsushima-Nishiwaki, R., Kanemura, N., Araki, H., Tsurumi, H., Kojima, S., Weinstein, I.B. and Moriwaki, H. (2007) Synergistic Effects of RXR Alpha and PPAR Gamma Ligands to Inhibit Growth in Human Colon Cancer Cells-Phosphorylated RXR Alpha Is a Critical Target for Colon Cancer Management. Gut, 56, 1557-1563. http://dx.doi.org/10.1136/gut.2007.129858

[62] Guruvayoorappan, C., Pradeep, C.R. and Kuttan, G. (2008) 13-cis-Retinoic Acid Induces Apoptosis by Modulating Caspase-3, bcl-2, and p53 Gene Expression and Regulates the Activation of Transcription Factors in B16F-10 Melanoma Cells. Journal of Environmental Pathology, Toxicology and Oncology, 27, 197-207. http://dx.doi.org/10.1615/JEnvironPatholToxicolOncol.v27.i3.40

[63] Hadjidaniel, M.D. and Reynolds, C.P. (2010) Antagonism of Cytotoxic Chemotherapy in Neuroblastoma Cell Lines by 13-cis-Retinoic Acid Is Mediated by the Antiapoptotic Bcl-2 Family Proteins. Molecular Cancer Therapeutics, 9, 3164-3174. http://dx.doi.org/10.1158/1535-7163.MCT-10-0078

[64] Vinik, A., Ullal, J., Parson, H.K. and Casellini, C.M. (2006) Diabetic Neuropathies: Clinical Manifestations and Current Treatment Options. Nature Clinical Practice Endocrinology Metabolism, 2, 269-281. http://dx.doi.org/10.1038/ncpendmet0142

[65] Hail Jr., N., Kim, H.J. and Lotan, R. (2006) Mechanisms of Fenretinide-Induced Apoptosis. Apoptosis, 11, $1677-1694$. http://dx.doi.org/10.1007/s10495-006-9289-3

[66] Lengfelder, E., Saussele, S., Weisser, A., Büchner, T. and Hehlmann, R. (2005) Treatment Concepts of Acute Promyelocytic Leukemia. Critical Reviews in Oncology/Hematology, 56, 261-274. http://dx.doi.org/10.1016/j.critrevonc.2004.08.009

[67] Recchia, F., Sica, G., Candeloro, G., Necozione, S., Bisegna, R., Bratta, M. and Rea, S. (2009) Beta-Interferon, Retinoids and Tamoxifen in Metastatic Breast Cancer: Long-Term Follow-Up of a Phase II Study. Oncology Reports, 21, 1011-1016. http://dx.doi.org/10.3892/or_00000317

[68] Anand, P., Terenghi, G., Warner, G., Kopelman, P., Williams-Chestnut, R.E. and Sinicropi, D.V. (1996) The Role of Endogenous Nerve Growth Factor in Human Diabetic Neuropathy. Nature Medicine, 2, 703-707. http://dx.doi.org/10.1038/nm0696-703

[69] Macejova, D., Baranova, M., Liska, J. and Brtko, J. (2005) Expression of Nuclear Hormone Receptors, Their Coregulators and Type I Iodothyronine 5'-Deiodinase Gene in Mammary Tissue of Nonlactating and Postlactating Rats. Life Sciences, 77, 2584-2593. http://dx.doi.org/10.1016/j.lfs.2005.02.024

[70] Li, Y. and Brown, P.H. (2009) Prevention of ER-Negative Breast Cancer. Recent Results in Cancer Research, 181, 121-134. http://dx.doi.org/10.1007/978-3-540-69297-3_13

[71] Pastorino, U., et al. (1993) Adjuvant Treatment of Stage I Lung Cancer with High-Dose Vitamin A. Journal of Clinical Oncology, 11, 1216-1222.

[72] Haugen, B.R., Larson, L.L., Pugazhenthi, U., Hays, W.R., Klopper, J.P., Kramer, C.A. and Sharma, V. (2004) Retinoic Acid and Retinoid X Receptors Are Differentially Expressed in Thyroid Cancer and Thyroid Carcinoma Cell Lines and Predict Response to Treatment with Retinoids. The Journal of Clinical Endocrinology Metabolism, 89, $272-280$. http://dx.doi.org/10.1210/jc.2003-030770

[73] Groome, P.A., Bolejack, V., Crowley, J.J., Kennedy, C., Krasnik, M., Sobin, L.H. and Goldstraw, P. (2007) The IASLC Lung Cancer Staging Project: Validation of the Proposals for Revision of the T, N, and M Descriptors and Consequent Stage Groupings in the Forthcoming (Seventh) Edition of the TNM Classification of Malignant Tumours. Journal of Thoracic Oncology, 2, 694-705. http://dx.doi.org/10.1097/JTO.0b013e31812d05d5

[74] Scagliotti, G.V., De Marinis, F., Rinaldi, M., Crinò, L., Gridelli, C., Ricci, S., Matano, E., Boni, C., Marangolo, M., Failla, G., Altavilla, G., Adamo, V., Ceribelli, A., Clerici, M., Di Costanzo, F., Frontini, L. and Tonato, M., For the Italian Lung Cancer Project (2002) Phase III Randomized Trial Comparing Three Platinum-Based Doublets in Advanced Non-Small-Cell Lung Cancer. Journal of Clinical Oncology, 20, 4285-4291. http://dx.doi.org/10.1200/JCO.2002.02.068

[75] Khuri, F.R., et al. (2001) Multi-Institutional Phase I/II Trial of Oral Bexarotene in Combination with Cisplatin and Vinorelbine in Previously Untreated Patients with Advanced Non-Small-Cell Lung Cancer. Journal of Clinical Oncology, 19, 2626-2637.

[76] Ramlau, R., Zatloukal, P., Jassem, J., Schwarzenberger, P., Orlov, S.V., Gottfried, M., Pereira, J.R., Temperley, G., Negro-Vilar, R., Rahal, S., Zhang, J.K., Negro-Vilar, A. and Dziewanowska, Z.E. (2008) Randomized Phase III Trial Comparing Bexarotene (L1069-49)/Cisplatin/Vinorelbine with Cisplatin/Vinorelbine in Chemotherapy-Naive Patients with Advanced or Metastatic Non-Small-Cell Lung Cancer: SPIRIT I. Journal of Clinical Oncology, 26, 1886-1892. 
http://dx.doi.org/10.1200/JCO.2007.12.2614

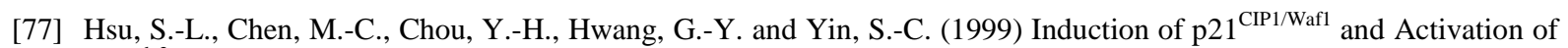
p34 ${ }^{\text {cdc2 }}$ Involved in Retinoic Acid-Induced Apoptosis in Human Hepatoma Hep3B Cells. Experimental Cell Research, 248, 87-96. http://dx.doi.org/10.1006/excr.1999.4397

[78] Klaassen, I., Brakenhoff, R.H., Smeets, S.J., Snow, G.B. and Braakhuis, B.J.M. (2001) Expression of Retinoic Acid Receptor Gamma Correlates with Retinoic Acid Sensitivity and Metabolism in Head and Neck Squamous Cell Carcinoma Cell Lines. International Journal of Cancer, 92, 661-665. http://dx.doi.org/10.1002/1097-0215(20010601)92:5<661::AID-IJC1251>3.0.CO;2-O

[79] Treat, J., Friedland, D., Luginbuhl, W., Meehan, L., Gorman, G., Miller, W., Bavaria, J. and Kaiser, L. (1996) Phase II Trial of All-Trans Retinoic Acid in Metastatic Non-Small Cell Lung Cancer. Cancer Investigation, 14, 415-420. http://dx.doi.org/10.3109/07357909609018898

[80] Huang, J., et al. (2002) Prostatic Intraepithelial Neoplasia in Mice with Conditional Disruption of the Retinoid X Receptor Alpha Allele in the Prostate Epithelium. Cancer Research, 62, 4812-4819.

[81] Thiruvengadam, R., Atiba, J.O. and Azawi, S.H. (1996) A Phase II Trial of a Differentiating Agent (tRA) with Cisplatin-VP 16 Chemotherapy in Advanced Non-Small Cell Lung Cancer. Investigational New Drugs, 14, 395-401. http://dx.doi.org/10.1007/BF00180817

[82] Arrieta, O., et al. (2010) Randomized Phase II Trial of All-Trans-Retinoic Acid with Chemotherapy Based on Paclitaxel and Cisplatin as First-Line Treatment in Patients with Advanced Non-Small-Cell Lung Cancer. Journal of Clinical Oncology, 28, 3463-3471. http://dx.doi.org/10.1200/JCO.2009.26.6452

[83] Zou, C.P., et al. (1998) Higher Potency of N-(4-Hydroxyphenyl)Retinamide than All-Trans-Retinoic Acid in Induction of Apoptosis in Non-Small Cell Lung Cancer Cell Lines. Clinical Cancer Research, 4, 1345-1355.

[84] Andrade, F.O., Nagamine, M.K., De Conti, A., Chaible, L.M., Fontelles, C.C., Jordão Jr., A.A., Vannucchi, H., Dagli, M.L.Z., Bassoli, B.K., Moreno, F.S. and Ong, T.P. (2012) Efficacy of the Dietary Histone Deacetylase Inhibitor Butyrate Alone or in Combination with Vitamin A against Proliferation of MCF-7 Human Breast Cancer Cells. Brazilian Journal of Medical and Biological Research, 45, 841-850. http://dx.doi.org/10.1590/S0100-879X2012007500103

[85] Hayashi, K., Yokozaki, H., Goodison, S., Oue, N., Suzuki, T., Lotan, R., Yasui, W. and Tahara, E. (2001) Inactivation of Retinoic Acid Receptor Beta by Promoter CpG Hypermethylation in Gastric Cancer. Differentiation, 68, 13-21. http://dx.doi.org/10.1046/j.1432-0436.2001.068001013.x

[86] Omenn, G.S., Goodman, G.E., Thornquist, M.D., Balmes, J., Cullen, M.R., Glass, A., Keogh, J.P., Meyskens, F.L., Valanis, B., Williams, J.H., Barnhart, S. and Hammar, S. (1996) Effects of a Combination of Beta Carotene and Vitamin A on Lung Cancer and Cardiovascular Disease. The New England Journal of Medicine, 334, 1150-1155. http://dx.doi.org/10.1056/NEJM199605023341802

[87] de Klerk, N.H., Musk, A.W., Ambrosini, G.L., Eccles, J.L., Hansen, J., Olsen, N., Watts, V.L., Lund, H.G., Pang, S.C., Beilby, J. and Hobbs, M.S.T. (1998) Vitamin A and Cancer Prevention II: Comparison of the Effects of Retinol and Beta-Carotene. International Journal of Cancer, 75, 362-367. http://dx.doi.org/10.1002/(SICI)1097-0215(19980130)75:3<362::AID-IJC6>3.0.CO;2-0

[88] Kamangar, F., Qiao, Y.-L., Yu, B.B., Sun, X.-D., Abnet, C.C., Fan, J.-H., Mark, S.D., Zhao, P., Dawsey, S.M. and Taylor, P.R. (2006) Lung Cancer Chemoprevention: A Randomized, Double-Blind Trial in Linxian, China. Cancer Epidemiology, Biomarkers Prevention, 15, 1562-1564. http://dx.doi.org/10.1158/1055-9965.EPI-06-0316

[89] The Alpha-Tocopherol Beta Carotene Cancer Prevention Study Group (1994) The Effect of Vitamin E and Beta Carotene on the Incidence of Lung Cancer and Other Cancers in Male Smokers. The New England Journal of Medicine, 330, 1029-1035. http://dx.doi.org/10.1056/NEJM199404143301501

[90] Hennekens, C.H., Buring, J.E., Manson, J.E., Stampfer, M., Rosner, B., Cook, N.R., Belanger, C., LaMotte, F., Gaziano, J.M., Ridker, P.M., Willett, W. and Peto, R. (1996) Lack of Effect of Long-Term Supplementation with Beta Carotene on the Incidence of Malignant Neoplasms and Cardiovascular Disease. The New England Journal of Medicine, 334, 1145-1149. http://dx.doi.org/10.1056/NEJM199605023341801

[91] Lippman, S.M., et al. (2001) Randomized Phase III Intergroup Trial of Isotretinoin to Prevent Second Primary Tumors in Stage I Non-Small-Cell Lung Cancer. Journal of the National Cancer Institute, 93, 605-618. http://dx.doi.org/10.1093/jnci/93.8.605

[92] De Vries, N., Van Zandwijk, N. and Pastorino, U. (1993) The EUROSCAN Study: A Progress Report. American Journal of Otolaryngology, 14, 62-66. http://dx.doi.org/10.1016/0196-0709(93)90014-X

[93] Lee, J.S., et al. (1993) Phase I Evaluation of All-Trans-Retinoic Acid in Adults with Solid Tumors. Journal of Clinical Oncology, 11, 959-966.

[94] Rigas, J.R. and Dragnev, K.H. (2005) Emerging Role of Rexinoids in Non-Small Cell Lung Cancer: Focus on Bexarotene. Oncologist, 10, 22-33. http://dx.doi.org/10.1634/theoncologist.10-1-22 
[95] van Zandwijk, N., Dalesio, O., Pastorino, U., de Vries, N. and van Tinteren, H., For the European Organization for Research and Treatment of Cancer Head and Neck and Lung Cancer Cooperative Groups (2000) EUROSCAN, a Randomized Trial of Vitamin A and N-Acetylcysteine in Patients with Head and Neck Cancer or Lung Cancer. For the European Organization for Research and Treatment of Cancer Head and Neck and Lung Cancer Cooperative Groups. Journal of the National Cancer Institute, 92, 977-986. http://dx.doi.org/10.1093/jnci/92.12.977

[96] Band, P.R., et al. (1982) Phase I Study of 13-cis-Retinoic Acid Toxicity. Cancer Treatment Reports, 66, $1759-1761$.

[97] Papadimitrakopoulou, V.A., Lee, J.J., William Jr., W.N., Martin, J.W., Thomas, M., Kim, E.S., Khuri, F.R., Shin, D.M., Feng, L., Hong, W.K. and Lippman, S.M. (2009) Randomized Trial of 13-cis Retinoic Acid Compared with Retinyl Palmitate with or without Beta-Carotene in Oral Premalignancy. Journal of Clinical Oncology, 27, 599-604. http://dx.doi.org/10.1200/JCO.2008.17.1850

[98] Weiss, G.R., Liu, P.Y., Alberts, D.S., Peng, Y.-M., Fisher, E., Xu, M.J., Scudder, S.A., Baker, L.H., Moore, D.F. and Lippman, S.M. (1998) 13-cis-Retinoic Acid or All-Trans-Retinoic Acid plus Interferon-Alpha in Recurrent Cervical Cancer: A Southwest Oncology Group Phase II Randomized Trial. Gynecologic Oncology, 71, 386-390. http://dx.doi.org/10.1006/gyno.1998.5204

[99] Toma, S., Vincenti, M., Palumbo, R., Muzio, G., Rainero, M.L., Santi, P. and Rosso, R. (1993) Results of the Association of Intralesional Recombinant Alpha-Interferon-2A (Alpha-IFN) plus 13-cis-Retinoic Acid (13cRA) in the Treatment of Basal-Cell Carcinomas (BCC) of the Skin. International Journal of Oncology, 3, 1149-1154. http://dx.doi.org/10.3892/ijo.3.6.1149

[100] Smith, B.D. and Wilson, L.D. (2003) Management of Mycosis Fungoides: Part 2. Treatment. Oncology (Williston Park), 17, 1419-1428.

[101] Whittaker, S.J., Marsden, J.R., Spittle, M. and Jones, R.R. (2003) Joint British Association of Dermatologists and U.K. Cutaneous Lymphoma Group Guidelines for the Management of Primary Cutaneous T-Cell Lymphomas. British Journal of Dermatology, 149, 1095-1107. http://dx.doi.org/10.1111/j.1365-2133.2003.05698.x

[102] Stoll, D., Binnert, C., Mooser, V. and Tappy, L. (2004) Short-Term Administration of Isotretinoin Elevates Plasma Triglyceride Concentrations without Affecting Insulin Sensitivity in Healthy Humans. Metabolism, 53, 4-10. http://dx.doi.org/10.1016/j.metabol.2003.07.006

[103] Querfeld, C., Nagelli, L.V., Rosen, S.T., Kuzel, T.M. and Guitart, J. (2006) Bexarotene in the Treatment of Cutaneous T-Cell Lymphoma. Expert Opinion on Pharmacotherapy, 7, 907-915. http://dx.doi.org/10.1517/14656566.7.7.907

[104] Dragnev, K.H., Petty, W.J., Shah, S., Biddle, A., Desai, N.B., Memoli, V., Rigas, J.R. and Dmitrovsky, E. (2005) Bexarotene and Erlotinib for Aerodigestive Tract Cancer. Journal of Clinical Oncology, 23, 8757-8764. http://dx.doi.org/10.1200/JCO.2005.01.9521

[105] Blumenschein Jr., G.R., Khuri, F.R., von Pawel, J., Gatzemeier, U., Miller Jr., W.H., Jotte, R.M., Le Treut, J., Sun, S.-L., Zhang, J.K., Dziewanowska, Z.E. and Negro-Vilar, A. (2008) Phase III Trial Comparing Carboplatin, Paclitaxel, and Bexarotene with Carboplatin and Paclitaxel in Chemotherapy-Naive Patients with Advanced or Metastatic Non-Small-Cell Lung Cancer: SPIRIT II. Journal of Clinical Oncology, 26, 1879-1885. http://dx.doi.org/10.1200/JCO.2007.12.2689

[106] Ruotsalainen, T., Halme, M., Isokangas, O.-P., Pyrhönen, S., Mäntylä, M., Pekonen, M., Sarna, S., Joensuu, H. and Mattson, K. (2000) Interferon-Alpha and 13-cis-Retinoic Acid as Maintenance Therapy after High-Dose Combination Chemotherapy with Growth Factor Support for Small Cell Lung Cancer-A Feasibility Study. Anti-Cancer Drugs, 11, 101-108. http://dx.doi.org/10.1097/00001813-200002000-00006

[107] Alvarez, R.D., et al. (2003) The Efficacy of 9-cis-Retinoic Acid (Aliretinoin) as a Chemopreventive Agent for Cervical Dysplasia: Results of a Randomized Double-Blind Clinical Trial. Cancer Epidemiology, Biomarkers Prevention, 12, 114-119.

[108] Lee, H.-Y., Chang, Y.S., Han, J.-Y., Liu, D.D., Lee, J.J., Lotan, R., Spitz, M.R. and Hong, W.K. (2005) Effects of 9-cis-Retinoic Acid on the Insulin-Like Growth Factor Axis in Former Smokers. Journal of Clinical Oncology, 23, 4439-4449. http://dx.doi.org/10.1200/JCO.2005.04.572

[109] Recchia, F., et al. (1997) Combined Chemotherapy and Differentiation Therapy in the Treatment of Advanced Non-Small-Cell Lung Cancer. Anticancer Research, 17, 3761-3765.

[110] Dragnev, K.H., Petty, W.J., Shah, S.J., Lewis, L.D., Black, C.C., Memoli, V., Nugent, W.C., Hermann, T., Negro-Vilar, A., Rigas, J.R. and Dmitrovsky, E. (2007) A Proof-of-Principle Clinical Trial of Bexarotene in Patients with Non-Small Cell Lung Cancer. Clinical Cancer Research, 13, 1794-800. http://dx.doi.org/10.1158/1078-0432.CCR-06-1836

[111] Rodon, J., Jacobs, C.D., Chu, Q., Rowinsky, E.K., Lopez-Anaya, A., Takimoto, C.H. and Wakelee, H.A. (2012) A Phase I Pharmacokinetic Study of Bexarotene with Paclitaxel and Carboplatin in Patients with Advanced Non-Small Cell Lung Cancer (NSCLC). Cancer Chemotherapy and Pharmacology, 69, 825-834. http://dx.doi.org/10.1007/s00280-011-1770-1 
[112] Edelman, M.J., Smith, R., Hausner, P., Doyle, L.A., Kalra, K., Kendall, J., Bedor, M. and Bisaccia, S. (2005) Phase II Trial of the Novel Retinoid, Bexarotene, and Gemcitabine plus Carboplatin in Advanced Non-Small-Cell Lung Cancer. Journal of Clinical Oncology, 23, 5774-5778. http://dx.doi.org/10.1200/JCO.2005.14.373

[113] Wakelee, H.A., Takimoto, C.H., Lopez-Anaya, A., Chu, Q., Middleton, G., Dunlop, D., Ramlau, R., Leighl, N., Rowinsky, E.K., Hao, D., Zatloukal, P., Jacobs, C.D. and Rodon, J. (2012) The Effect of Bexarotene on Atorvastatin Pharmacokinetics: Results from a Phase I Trial of Bexarotene plus Chemotherapy in Patients with Advanced Non-Small Cell Lung Cancer. Cancer Chemotherapy and Pharmacology, 69, 563-571. http://dx.doi.org/10.1007/s00280-011-1772-z

[114] Athanasiadis, I., et al. (1995) Phase II Study of All-Trans-Retinoic Acid and Alpha-Interferon in Patients with Advanced Non-Small Cell Lung Cancer. Clinical Cancer Research, 1, 973-979.

[115] Nandan, R. (2006) Promising Results Achieved with a Combination of Chemotherapy and Two Retinoids in Patients with Advanced Non-Small-Cell Lung Cancer. Lung Cancer, 51, 387-388. http://dx.doi.org/10.1016/j.lungcan.2005.11.003

[116] Norsa, A. and Martino, V. (2006) Somatostatin, Retinoids, Melatonin, Vitamin D, Bromocriptine, and Cyclophosphamide in Advanced Non-Small-Cell Lung Cancer Patients with Low Performance Status. Cancer Biotherapy and Radiopharmaceuticals, 21, 68-73. http://dx.doi.org/10.1089/cbr.2006.21.68

[117] Hittelman, W.N., Liu, D.D., Kurie, J.M., Lotan, R., Lee, J.S., Khuri, F., Ibarguen, H., Morice, R.C., Walsh, G., Roth, J.A., Minna, J., Ro, J.Y., Broxson, A., Hong, W.K. and Lee, J.J. (2007) Proliferative Changes in the Bronchial Epithelium of Former Smokers Treated with Retinoids. Journal of the National Cancer Institute, 99, 1603-1612. http://dx.doi.org/10.1093/jnci/djm205

[118] Pillai, R.N., Aisner, J., Dahlberg, S.E., Rogers, J.S., DiPaola, R.S., Aisner, S., Ramalingam, S.S. and Schiller, J.H. (2014) Interferon Alpha plus 13-cis-Retinoic Acid Modulation of BCL-2 plus Paclitaxel for Recurrent Small-Cell Lung Cancer (SCLC): An Eastern Cooperative Oncology Group Study (E6501). Cancer Chemotherapy and Pharmacology, 74, 177-183. http://dx.doi.org/10.1007/s00280-014-2427-7

[119] Recchia, F., et al. (2001) Phase 1B Study of Subcutaneously Administered Interleukin 2 in Combination with 13-cis Retinoic Acid as Maintenance Therapy in Advanced Cancer. Clinical Cancer Research, 7, 1251-1257.

[120] Kelly, K., Kittelson, J., Franklin, W.A., Kennedy, T.C., Klein, C.E., Keith, R.L., Dempsey, E.C., Lewis, M., Jackson, M.K., Hirsch, F.R., Bunn, P.A. and Miller, Y.E. (2009) A Randomized Phase II Chemoprevention Trial of 13-CIS Retinoic Acid with or without Alpha Tocopherol or Observation in Subjects at High Risk for Lung Cancer. Cancer Prevention Research (Phila), 2, 440-449. http://dx.doi.org/10.1158/1940-6207.CAPR-08-0136 